\title{
Physicochemical, Biochemical and Instrumental Attributes and Consumer Acceptability of Dry-Fermented Sausages Elaborated with Combined Partial Substitutions of Sodium Chloride and Pork Backfat
}

\author{
Hassan Safa, Philippe Gatellier, Jean-Louis Berdagué, Nathalie Kondjoyan, Frédéric Mercier, \\ Stéphane Portanguen, Raphaël Favier, Pierre-Sylvain Mirade
}

QuaPA, INRA, Saint-Genès-Champanelle, France

Email:pierre-sylvain.mirade@clermont.inra.fr

How to cite this paper: Safa, H., Gatellier, P., Berdagué, J.-L., Kondjoyan, N., Mercier, F., Portanguen, S., Favier, R. and Mirade, P.-S. (2016) Physicochemical, Biochemical and Instrumental Attributes and Consumer Acceptability of Dry-Fermented Sausages Elaborated with Combined Partial Substitutions of Sodium Chloride and Pork Backfat. Food and Nutrition Sciences, 7, 1297-1314. http://dx.doi.org/10.4236/fns.2016.714119

Received: September 26, 2016

Accepted: December 2, 2016

Published: December 5, 2016

Copyright $\odot 2016$ by authors and Scientific Research Publishing Inc. This work is licensed under the Creative Commons Attribution International License (CC BY 4.0).

http://creativecommons.org/licenses/by/4.0/

\section{(c) (i) Open Access}

\begin{abstract}
We performed 6 fabrications of dry-fermented sausages to investigate, at laboratory scale, the effects of combined partial substitutions of sodium chloride by potassium chloride and pork backfat by sunflower oil on key physical-chemical and biochemical parameters, instrumental colour and texture measurements, and the consumer acceptability of the end-products. Regarding the physical-chemical parameters, statistical analysis of results showed that final product weight loss was impacted by fat content and use of sunflower oil; final mean water activity value was only affected by salt level; and animal fat content impacted $\mathrm{pH}$ values, only at the end of drying. Regarding the biochemical parameters investigated, we statistically found a marked impact of partial substitution of $\mathrm{NaCl}$ by $\mathrm{KCl}$ on the proteolysis evolution, of fat level and sodium content on the end-product lipolysis, and finally, a significant effect of animal fat level and incorporation of sunflower oil on both protein and lipid oxidations. However, the new product formulations combining salt and fat substitutions lead to globally acceptable water loss and water activity values and similar rates of proteolysis, lipolysis and lipid oxidation, but less protein oxidation. From a practical point of view, the results clearly showed that sodium and animal fat contents in dryfermented sausages can be drastically reduced with no too marked adverse effect on colour, final textural properties or consumer acceptability. On the basis of these laboratory results, new healthier dry-fermented products can be manufactured by an industrial company in the near future.
\end{abstract}




\section{Keywords}

Dry-Fermented Sausage, Combined Partial Substitutions, KCl, Sunflower Oil, Oxidation

\section{Introduction}

In Europe, processed meats such as dry-fermented sausage (DFS) are staple ways of transforming and conserving meat. However, their production has always used large amounts of curing agents like salt that, if consumed in excess, are related to the development of human health problems: high blood pressure and cardiovascular diseases [1]. Furthermore, DFS are typically rich in saturated fatty acids (SFA), and an excessive intake of fat in human diet has been implicated as a driver of hypercholesterolemia and coronary heart disease [2] [3]. For these reasons, health authorities have recommended cutting fat intake down to less than $30 \%$ of total caloric intake, keeping polyunsaturated-to-saturated fatty acids ratio between 0.4 and 0.5 , and cutting salt intake down to just $6 \mathrm{~g}$ salt per day from the current average daily $\mathrm{NaCl}$ intake estimated at between 8.3 and $10 \mathrm{~g}$ of salt [4]. Reducing salt and fat intake in human diet hinges on reducing the consumption of processed meat products, which contribute up to $22 \%-24 \%$ of $\mathrm{NaCl}$ intake and $50 \%$ of total calorie intake [4] [5]. However, meat industry efforts to strongly reduce fat and salt have often failed due to the crucial functions played by salt and fat in processed meat products. For example, texture, aroma and taste defects and lower overall consumer acceptability have been reported in low-salt slow-fermented sausages [6] and low-fat fermented sausages [7]. Industry efforts to improve the DFS nutritional quality have therefore turned to the partial substitutions of salt with other free-sodium salts [1] [6] [8] [9] [10] and of pork backfat with other sources of more polyunsaturated fatty acid-rich fat such as vegetable oils [3] [4] [7] [11]. However, salt and animal fat substitutions could equally have physicochemical, organoleptic and sensory impacts on DFS quality. Several papers report no significant effects on textural features when animal fat was partially substituted by olive oil [3] [7] [12] [13]. In contrast, a study on salami found lower firmness when animal fat was replaced with extra-virgin olive oil [4] and a study on non-acid-fermented sausages made with 5\% sunflower oil (SFO) found that the end-products were more cohesive and very springy but softer and less chewy [11]. The literature contains several reports of effects of salt substitution on textural features. For example, harder products were obtained when sausages were made with partial replacement of $\mathrm{NaCl}$ with $\mathrm{KCl}$ [1] [6] [10] [14]. It was also reported that partial replacement of salt by divalent salts such as calcium chloride leads to harder, more cohesive and chewier sausages [15]. Concerning flavour, taste and aroma, fermented sausages made with $8 \%$ pork backfat and $2 \%$ olive oil were found to have intense odour and taste [7] and non-acid-fermented sausages made with 5\% SFO had a more intense ripened odour and flavour [11]. In contrast, metallic flavour and taste and aroma defects were detected in sausages made with high levels (>33\%) of KCl [9] [14]. Further- 
more, using high amounts of K-Lactate reduced the cured colour intensity as a result of higher $\mathrm{pH}$ values at the end of fermentation [10], and partial substitution of $\mathrm{NaCl}$ with mixtures of $\mathrm{KCl}$ and calcium chloride or calcium ascorbate led to lighter and yellower sausages [8] [9]. However, very few studies have investigated the combined substitution of $\mathrm{NaCl}$ and pork backfat during dry sausage manufacture. Beriain et al. [16] studied the effect of incorporating emulsified olive oil on the physicochemical properties of low-salt, inulin-enriched dried sausages. Mora-Gallego et al. [17] investigated the effect of replacing pork fat by SFO on the physicochemical, instrumental and sensory characteristics of small low-sodium non-acid fermented sausages. Safa et al. [18] recently reported that direct combined reductions of fat and salt content increased product weight losses, water activity, proteolysis and lactic fermentation, while decreasing lipolysis and oxidation.

The final objective of the present project is to industrially manufacture DFS with a binary reduction of $30 \%$ in sodium and $60 \%$ in SFA, which are acceptable to consumers. Preliminary pilot experiments showed that these reductions are achievable only by partially substituting $\mathrm{NaCl}$ with $\mathrm{KCl}$ and directly reducing added pork backfat by using lean pork meat containing just 7\% fat, and are maintained when $3 \%$ SFO is added to reach a similar level of unsaturated fatty acids to conventional products. Here, at laboratory scale, we ran an in-depth analysis of 6 DFS fabrications of varying composition to quantify how and to what extent combined partial substitutions of $\mathrm{NaCl}$ by $\mathrm{KCl}$ and pork backfat by SFO affect the time-course of key biochemical reactions occurring in DFS manufacture as well as the physicochemical, instrumental and sensory characteristics of end-products.

\section{Materials and Methods}

\subsection{Dry-Fermented Sausage Manufacture}

Pieces of pork shoulder and pork backfat were purchased from a local distributor. At reception, the water content, $\mathrm{pH}$ and water activity $\left(\mathrm{a}_{\mathrm{w}}\right)$ of the pork lean were verified as water content $=74.0 \% \pm 0.5 \%, \mathrm{pH}=5.99 \pm 0.03, \mathrm{a}_{\mathrm{w}}=0.971 \pm-0.002$. In total, six DFS formulations of varying composition were manufactured (Table 1). The first formulation (Control) was prepared mainly using more than $70 \%$ pork lean, $21 \%$ animal fat ( $7 \%$ contained in the lean meat plus $14 \%$ added pork backfat), $2.8 \% \mathrm{NaCl}$ and flavouring $(0.5 \mathrm{~g} / \mathrm{kg}$ of garlic plus $2 \mathrm{~g} / \mathrm{kg}$ of black pepper). The second fabrication corresponded to a reduced-sodium formulation that contained $0.8 \%-\mathrm{KCl}$ (K-RS). The third and fourth fabrications, prepared only with lean meat, corresponded to reduced-fat formulations which were not combined (RF) or combined with partial replacement of $\mathrm{NaCl}$ by $\mathrm{KCl}$ (K-RSF). The last two fabrications corresponded to reduced-fat formulations containing $3 \%$ SFO without (SFO-RF) or with (K-SFO-RSF) partial substitution of $\mathrm{NaCl}$ by $\mathrm{KCl}$.

For each formulation (Table 1), three replicates were performed with, at each time, about 30 DFS manufactured as per the procedure reported in Safa et al. [18]. The incorporation of $3 \%$ total matter (TM) SFO (previously stored at $-2^{\circ} \mathrm{C}$ ) in the products of 
Table 1. Details of the experimental formulations of dry-fermented sausages tested in this study (percentages are expressed as a function of total matter).

\begin{tabular}{|c|c|c|c|c|c|c|}
\hline Formulations & Code & $\begin{array}{l}\text { Animal fat } \\
\text { content (\%) }\end{array}$ & $\begin{array}{l}\text { Sunflower oil } \\
\text { content }(\%)\end{array}$ & $\begin{array}{c}\text { Wheat } \\
\text { fibres (\%) }\end{array}$ & $\begin{array}{c}\mathrm{NaCl} \\
\text { content (\%) }\end{array}$ & $\begin{array}{c}\mathrm{KCl} \\
\text { content }(\%)\end{array}$ \\
\hline Reference & Control & 21 & 0 & 0 & 2.8 & 0 \\
\hline Sodium reduction & K-RS & 21 & 0 & 0 & 2.0 & 0.8 \\
\hline Animal fat reduction & $\mathrm{RF}$ & 7 & 0 & 0 & 2.8 & 0 \\
\hline Sodium reduction + Animal fat reduction & K-RSF & 7 & 0 & 0 & 2.0 & 0.8 \\
\hline Animal fat reduction + Animal fat replacement & SFO-RF & 7 & 3 & 1 & 2.8 & 0 \\
\hline $\begin{array}{l}\text { Sodium reduction }+ \text { Animal fat reduction }+ \\
\text { Animal fat replacement }\end{array}$ & K-SFO-RSF & 7 & 3 & 1 & 2.0 & 0.8 \\
\hline
\end{tabular}

formulations SFO-RF and K-SFO-RSF required the prior preparation of an emulsion with lean pork meat and the addition of $10 \mathrm{~g} / \mathrm{kg}$ TM wheat plant fibres (WF200, Rettenmaier \& Son, Rosenberg, Germany) to bind the batter and minimize further oil loss in liquid form. All products were steamed for 4 days at $24^{\circ} \mathrm{C}$ and $70 \%$ relative humidity (RH), then ripened for 25 days at $13^{\circ} \mathrm{C}$ and $70 \% \mathrm{RH}-$ i.e. a total drying time of 29 days-in a ventilated temperature- and $\mathrm{RH}$-controlled room.

For each replicated fabrication, three sausages were taken at days 7 and 29 to evaluate the physicochemical parameters and at days 1, 7, 21 and 29 to evaluate the time-course patterns of biochemical parameters. For biochemical analyses, all the sausages were individually treated with liquid nitrogen, ground down into fine powder to minimize problems tied to heterogeneity of sampling in subsequent analysis, and stored at $-80^{\circ} \mathrm{C}$ until analysis.

\subsection{Physical-Chemical Analyses}

\subsubsection{Product Weight Loss}

Almost every day of drying, for each replicated formulation, the weight of 9 dry sausages arranged on the same bar was measured to determine percentage weight loss. To avoid any impact of potential heterogeneities of the drying conditions on product weight losses, the location of the bars inside the room was changed after each weight measurement. Weight loss was expressed as percentage of initial weight.

\subsubsection{Water Activity}

Water activity $\left(\mathrm{a}_{\mathrm{w}}\right)$ was measured at $20^{\circ} \mathrm{C}$ using a lab $\mathrm{a}_{\mathrm{w}}$-meter (aw Sprint TH-500, Novasina, Switzerland). Preliminary $\mathrm{a}_{\mathrm{w}}$ measurements were realized individually on three dry sausages corresponding to each formulation. Since no significant difference between the three values ( $<0.001 a_{w}$ unit) was found, $a_{w}$ values for each replicated formulation were thus determined on a mixture of the three dry sausages.

\subsection{3. pH Values}

$\mathrm{pH}$ was determined using $1 \mathrm{~g}$ of powdered-down sample previously homogenized with 
$10 \mathrm{~mL}$ of ultrapure water (Ultra-Turrax system, Ika, Germany). $\mathrm{pH}$ was measured with a pH meter (InLab427, Mettler Toledo, France) calibrated with standard solutions at $\mathrm{pH} 4$ and $\mathrm{pH}$ 7. All pH measurements were performed in nine replicates.

\subsection{Biochemical Analyses}

All these biochemical analyses were performed in nine samples corresponding to 3 sausages of each replicated formulation.

\subsubsection{Proteolysis}

Proteolysis index (PI) was determined on powdered-down samples of products based on a fluorescence method using the reaction of fluorescamine with $\mathrm{N}$-terminal $\alpha$-amino groups of peptides in TCA-soluble fractions [19]. The method defines PI as the percentage ratio of amino group content to total protein content.

\subsubsection{Lipolysis}

Fat degradation into fatty acids was quantified by determining the acid value of fat (standard NF T 60-204) in samples of 29-day-old DFS. Total free fatty acid content from $25 \mathrm{~g}$ of sample was dissolved in a solvent mix of ether/ethanol and quantified by potassium hydroxide $(0.1 \mathrm{~N})$ in the presence of phenolphthalein (acid medium) which is colourless before neutralization but turns pink after neutralization under basic conditions. The number of equivalents of potassium hydroxide poured is equal to the number of equivalents of acid present in the sample. The acid value is thus the mass of potassium hydroxide (in $\mathrm{mg}$ ) required to neutralize $1 \mathrm{~g}$ of fat.

\subsubsection{Lipid Oxidation}

Lipid oxidation was assessed in DFS powdered-down samples by determining fluorescent Hydrosoluble Schiff bases (HSB). For this purpose, the aqueous phase obtained during the determination of fat content was collected and used to quantify HSB levels. In parallel, a standard curve of commercial quinine was prepared. Fluorescence of each point of the standard curve and fluorescence of each sample were measured with a spectrofluorometer (FP 8300, Jasco, France) at a $370 \mathrm{~nm}$ excitation wavelength, a 470 $\mathrm{nm}$ emission wavelength and a $3 \mathrm{~s}$ integration time. A linear standard curve of quinine was plotted, and sample HSB levels were calculated from this curve and expressed as micromoles/kg meat vs. quinine equivalent.

\subsubsection{Protein Oxidation}

Thiol groups of cysteine are very sensitive to the oxidative process and their oxidation leads to the formation of disulphide bridges. The decrease of free-thiol-group content can therefore be used to measure protein oxidation. Protein oxidation was assessed in DFS powdered-down samples through the determination of free thiol groups of cysteine residues from Ellman's assay using 2,2'-dithiobis (5-nitropyridine) (DTNP) as reagent. Under alkaline conditions, DTNP binds to the anionic free thiol groups of cysteine residues to form a complex that absorbs at $386 \mathrm{~nm}$. The results were expressed in nanomoles of bound DTNP per mg of protein. 


\subsection{Instrumental and Sensory Characteristics of Dry-Fermented Sausages}

\subsubsection{Colour}

Colour was recorded using a Konica Minolta CM 2500d (Japan) spectrocolorimeter in the CIELAB colour space (D65-10 $\left.-\mathrm{L}^{\star} \mathrm{a}^{*} \mathrm{~b}^{*}-\mathrm{d} / 8 \mathrm{SCE}\right)$. The instrument was calibrated at 0 (in the air) and with white standard (No. 7009694). Colour was measured on the top of the DFS slices. For each product formulation, the colour data reported here corresponded to the average of 15 local measurements performed on three whole product slices.

\subsubsection{Texture}

DFS quality was evaluated through texture measurements on non-frozen $30 \times 20 \times 50$ mm parallelepiped samples extracted from 29-day-old products. A TA.XT Plus universal texture analyser (Stable Micro Systems Ltd., Surrey, England) was used to perform the texture profile analysis (TPA) tests at room temperature. The $20 \mathrm{~mm}$-high parallelepiped samples were placed under the compression plate surface (flat $490 \mathrm{~mm}^{2}$ cross-section plunger) and twice compressed axially to $50 \%$ of their original height with a time interval of $2 \mathrm{~s}$ between the two successive compressions. The TPA parameters obtained using the XT.RA Dimension software package delivered with the experimental device were hardness, fragility, elasticity and cohesiveness. Texture measurements were performed in six samples.

\subsubsection{Consumer Acceptability Analysis}

End-product quality was also evaluated through a consumer acceptability analysis performed by 29 assessors accustomed to eating dry sausages and repeated twice. Scoring was carried out using a structured scoring scale (from 0 "low score" to 10 "high score"). During each consumer analysis, six DFS slices, corresponding to the 6 product formulations, were presented to the assessors in random order. Four product acceptability criteria were studied: appearance, mouthfeel, taste and aroma.

\subsection{Statistical Analyses}

Hierarchical cluster analysis (HCA), calculated using Ward's method on STATISTICA 10-V2014 software, was applied to all measured raw values to make the figures easier to read and the results easier to interpret. HCA consists in clustering samples that lead to similar results on a given parameter, thereby creating classes of formulations. Once a class of formulations of sausages is formed, the values of the parameter corresponding to the class are calculated, at each time point, by averaging the values of all the sameclass formulations of sausages.

To assess the effect of each factor (fat and salt contents, and SFO use) and of some interactions between the factors (salt content $\times$ fat content, and salt content $\times$ SFO content) on each variable measured in this study, statistical analyses of the results were performed by analysis of variance (ANOVA) using STATISTICA 10-V2014 software. Note that we have firstly checked that the factor "formulation" had no significant effect 
( $p>0.05$ ) on each physicochemical and biochemical parameter measured in this study. When ANOVA found a significant effect $(\mathrm{p}<0.05)$, post-hoc procedures were used and multiple comparisons among means were examined by the Tukey test to determine the level of significance between groups.

For the results of consumer acceptability analysis, the effects of formulations on acceptability scores for product appearance, mouthfeel, taste and aroma were evaluated by ANOVA using the model:

Acceptability

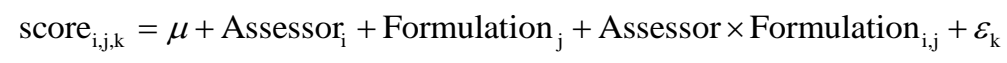

where $\mu$ is mean effect, Assessor is assessor effect (29 assessors), Formulation is formulation effect ( 6 levels), Assessor $\times$ Formulation $_{\mathrm{i}, \mathrm{j}}$ represents the interactions between formulations and assessors, and $\varepsilon_{k}$ is the residual variance. Means were compared by a Tukey test $(p<0.05)$.

\section{Results and Discussion}

\subsection{Physical-Chemical Analyses}

\subsubsection{Product Weight Loss}

At the end of ripening, product weight losses ranged from $41.5 \%$ to $50.2 \%$ depending on formulation (Table 2). Regardless of initial salt content, a higher fat level equates to lower percentage weight losses (41.5\% for experiments Control and K-RS, respectively). Moreover, replacing $\mathrm{NaCl}$ by $\mathrm{KCl}$ at a $30 \%$ level had no significant effect on percentage weight loss at the end of drying $(p>0.05)$. In contrast, reducing the initial animal fat level from $21 \%$ to $7 \%$ with or without adding $3 \%$ SFO increased product weight losses, which ranged from $45.8 \%$ to $50.2 \%$ for formulations RF, K-RSF, SFO-RF and K-SFORSF. In-depth analysis found that incorporating 3\% SFO to $7 \%$ animal fat led to slightly higher weight loss, probably as result of higher oil loss in liquid form during the fermentation stage. Indeed, we noted that the surface of the products corresponding to the two formulations with added SFO remained visibly "oily" throughout the first week of process. For these two batches, product weight losses at the end of drying ranged from $49.2 \%$ (SFO-RF) to $50.2 \%$ (K-SFO-RSF).

ANOVA and Tukey test (Table 2) highlighted very highly significant effects of fat content and use of SFO $(p<0.001)$ on final product weight loss but no significant effect of salt content or the two interactions studied $(p>0.05)$. These results, showing that product weight losses are highest when animal fat content is reduced and vegetable oil is added, confirm results previously obtained by [20] [21]. Indeed, Muguerza et al. [21] reported substantial dripping of liquid oil during the manufacture of healthier dried Chorizo de Pamplona sausages, which they explained by the fact that higher unsaturation of fatty acids in this type of oil made it more fluid.

\subsubsection{Water Activity Values}

At day 29, mean $\mathrm{a}_{\mathrm{w}}$ values ranged from 0.884 to 0.896 (Table 2), thus ensuring product safety as all these $a_{w}$ values were comfortably below the "safe" threshold value of 0.92 
Table 2. Details of statistical analyses: (a) analysis of variance, (b) physical-chemical parameters measured (weight loss, $\mathrm{a}_{\mathrm{w}}, \mathrm{pH}$ ) and (c) post-hoc procedure performed on the values of biochemical parameters (proteolysis, lipolysis, lipid and protein oxidations) for all 6 formulations of dry-fermented sausages. ANOVA was performed to study the effect of salt content, fat content, sunflower oil (SFO) content, and salt content $\times$ fat content and salt content $\times$ SFO content interactions on the physical-chemical and biochemical parameters studied; significance is annotated as: $\mathrm{ns}(p>0.05),{ }^{\star}(p<0.05),{ }^{\star *}(p<0.01),{ }^{* *}(p<0.001)$; a Tukey test was applied on the means \pm standard deviation calculated from all independent determinations and for all time points, and values not bearing common superscripts differed significantly at $p<0.05$.

(a) Analysis of variance (ANOVA)

\begin{tabular}{|c|c|c|c|c|c|c|c|c|}
\hline & $\begin{array}{l}\text { Weight losses } \\
\text { (day 29) }\end{array}$ & $a_{w}($ day 29$)$ & $\mathrm{pH}($ day 7$)$ & $\mathrm{pH}($ day 29) & $\begin{array}{c}\text { Proteolysis } \\
\text { (Proteolysis index) }\end{array}$ & $\begin{array}{c}\text { Lipolysis (Acidity } \\
\text { value) }\end{array}$ & $\begin{array}{l}\text { Lipid oxidation } \\
\text { (HSB) }\end{array}$ & $\begin{array}{c}\text { Protein oxidation } \\
\text { (Thiol groups) }\end{array}$ \\
\hline Salt & ns & $* * *$ & ns & $\mathrm{ns}$ & $* * *$ & $* * *$ & ns & ns \\
\hline Fat & $* * *$ & ns & ns & $* * *$ & ns & $* * *$ & $* * *$ & $* * *$ \\
\hline SFO & $* * *$ & ns & ns & ns & ns & ns & $* * *$ & $* * *$ \\
\hline Salt $\times$ Fat & ns & ns & ns & ns & ns & ns & ns & ns \\
\hline Salt $\times$ SFO & ns & ns & ns & ns & ns & ns & ns & ns \\
\hline \multicolumn{5}{|c|}{ (b) Physical-chemical measurements } & \multicolumn{4}{|c|}{ (c) Post-hoc procedure (Tukey test) } \\
\hline & $\begin{array}{l}\text { Weight losses } \\
\text { (day 29) }\end{array}$ & $a_{w}($ day 29$)$ & $\mathrm{pH}($ day 7$)$ & $\mathrm{pH}($ day 29) & $\begin{array}{c}\text { Proteolysis } \\
\text { (Proteolysis index) }\end{array}$ & $\begin{array}{c}\text { Lipolysis (Acidity } \\
\text { value) }\end{array}$ & $\begin{array}{l}\text { Lipid oxidation } \\
\text { (HSB) }\end{array}$ & $\begin{array}{c}\text { Protein oxidation } \\
\text { (Thiol groups) }\end{array}$ \\
\hline Control & $41.5 \pm 0.1^{\mathrm{a}}$ & $0.884 \pm 0.002^{\mathrm{a}}$ & $5.00 \pm 0.06^{\mathrm{a}}$ & $5.31 \pm 0.03^{\mathrm{a}}$ & $4.3 \pm 0.8^{\mathrm{a}}$ & $9.7 \pm 0.3^{\mathrm{b}}$ & $2.71 \pm 1.14^{c}$ & $21.8 \pm 1.5^{\mathrm{a}}$ \\
\hline K-RS & $41.5 \pm 0.2^{\mathrm{a}}$ & $0.894 \pm 0.001^{\mathrm{b}}$ & $5.04 \pm 0.04^{\mathrm{a}}$ & $5.34 \pm 0.04^{\mathrm{a}}$ & $4.5 \pm 0.9^{\mathrm{b}}$ & $12.3 \pm 0.5^{\mathrm{d}}$ & $2.73 \pm 1.11^{\mathrm{c}}$ & $22.1 \pm 1.4^{\mathrm{a}}$ \\
\hline $\mathrm{RF}$ & $45.8 \pm 0.2^{\mathrm{b}}$ & $0.886 \pm 0.002^{\mathrm{a}}$ & $5.05 \pm 0.05^{\mathrm{a}}$ & $5.43 \pm 0.04^{\mathrm{b}}$ & $4.4 \pm 1.0^{\mathrm{ab}}$ & $7.4 \pm 0.3^{\mathrm{a}}$ & $2.20 \pm 0.96^{\mathrm{a}}$ & $30.2 \pm 1.5^{\mathrm{c}}$ \\
\hline K-RSF & $47.0 \pm 0.2^{\mathrm{bc}}$ & $0.894 \pm 0.002^{\mathrm{b}}$ & $5.02 \pm 0.04^{\mathrm{a}}$ & $5.44 \pm 0.02^{\mathrm{b}}$ & $4.6 \pm 1.0^{c}$ & $8.6 \pm 0.2^{\mathrm{ab}}$ & $2.16 \pm 0.98^{\mathrm{a}}$ & $29.9 \pm 1.6^{c}$ \\
\hline SFO-RF & $49.2 \pm 0.4^{\mathrm{c}}$ & $0.889 \pm 0.002^{\mathrm{a}}$ & $5.01 \pm 0.01^{\mathrm{a}}$ & $5.47 \pm 0.05^{\mathrm{b}}$ & $4.5 \pm 1.0^{\mathrm{b}}$ & $10.5 \pm 0.3^{c}$ & $2.53 \pm 1.08^{\mathrm{b}}$ & $28.6 \pm 1.5^{\mathrm{b}}$ \\
\hline K-SFO-RSF & $50.2 \pm 0.5^{c}$ & $0.896 \pm 0.003^{\mathrm{b}}$ & $5.05 \pm 0.04^{\mathrm{a}}$ & $5.49 \pm 0.02^{\mathrm{b}}$ & $4.6 \pm 1.0^{c}$ & $10.0 \pm 0.3^{\mathrm{b}}$ & $2.47 \pm 1.13^{\mathrm{b}}$ & $28.7 \pm 1.4^{\mathrm{b}}$ \\
\hline
\end{tabular}

for growth capacity of Listeria monocytogenes.

ANOVA and Tukey test (Table 2 ) showed that mean $\mathrm{a}_{\mathrm{w}}$ value was only significantly affected by salt level $(p<0.001)$. The highest $\mathrm{a}_{\mathrm{w}}$ values $\left(\mathrm{a}_{\mathrm{w}}>0.89\right)$ were obtained for the three formulations made with partial substitution of $\mathrm{NaCl}$ by $\mathrm{KCl}$ (Table 2), thus confirming the lower $\mathrm{a}_{\mathrm{w}}$-depressor effect of $\mathrm{KCl}$ compared to $\mathrm{NaCl}$. These findings are in good agreement with [22] [23], e.g. higher $\mathrm{a}_{\mathrm{w}}$ values were reported in DFS made with a salt mixture containing $1.00 \% \mathrm{NaCl}, 0.55 \% \mathrm{KCl}, 0.23 \% \mathrm{MgCl}_{2}$, and $0.46 \% \mathrm{CaCl}_{2}$.

\subsection{3. pH Values}

$\mathrm{pH}$ value was measured at the end of fermentation (day 7) and again at the end of drying (day 29) (Table 2). In all formulations, an acidic $\mathrm{pH}$ value close to 5.0 was logically obtained at day 7 as a result of the action of lactic acid bacteria (LAB) converting sugars into lactic acid. This acidification during fermentation contributes to the DFS safety, along with drying, added salt and low $\mathrm{a}_{\mathrm{w}}$ values. $\mathrm{pH}$ values increased in all formulations from day 7 to day 29 , driven by the transformation of lactic acid into other chemical substances and the production of alkaline molecules due to proteolysis [24]. The highest final $\mathrm{pH}$ values were measured in fat-reduced dried sausages [25] but all the $\mathrm{pH}$ 
values obtained are acceptable as they mirror the $\mathrm{pH}$ values classically found in DFS.

ANOVA and Tukey (Table 2 ) test showed that $\mathrm{pH}$ values were only affected, at the end of drying, by level of animal fat $(p<0.001)$. This finding is in line with the results reported in [6] [9] [10] [14] [23] [25], but diverge from the results obtained by [11] [20] [21] [26] where no significant differences between $\mathrm{pH}$ and/or lactic bacteria counts were found when comparing control dry sausages with products elaborated with partial substitution of $\mathrm{NaCl}$ with $\mathrm{KCl}$ or low-fat-content sausages.

\subsection{Biochemical Parameters}

\subsubsection{Time-Course of Proteolysis}

Figure 1(a) charts the time-course of proteolysis measured in DFS. A close look at Figure 1(a) shows that proteolytic activity is detectable straight from day 1 , as proteolytic enzymes are already active at $24^{\circ} \mathrm{C}$ and bacterial enzymes at work during the fermentation stage contribute to the initial degradation of myofibrillar proteins, especially the
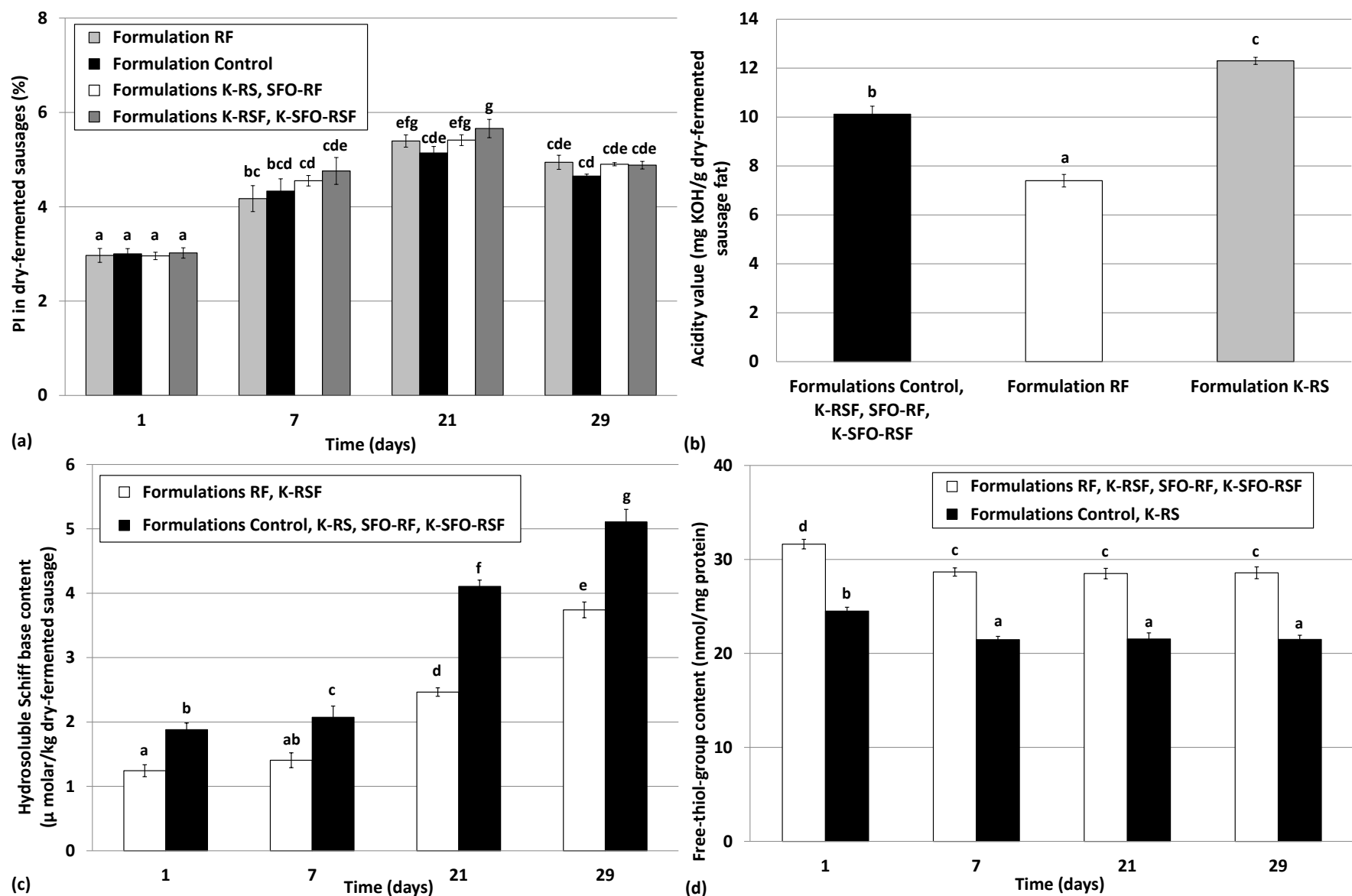

(b)

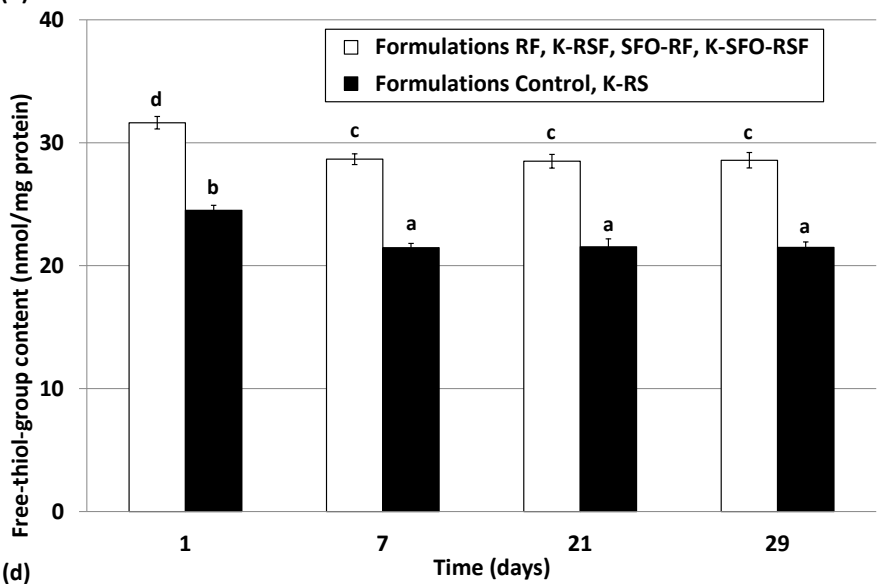

Figure 1. Evolution of four biochemical reactions investigated in the six formulations of dry-fermented sausages: (a) time-course of proteolysis index, (b) rate of lipolysis quantified through an acidity value at day 29, (c) lipid oxidation quantified by determining hydrosoluble Schiff base (HSB) content and (d) protein oxidation quantified by determining free-thiol-group content. Hierarchical cluster analysis was performed on raw values in order to pool product formulations presenting similar patterns; for each class of dried sausages, values are means \pm standard deviation calculated from all the independent measured values of each formulation in that class and values not bearing common superscripts differed significantly at $p<0.05$. 
release of free amino acids from myosin and actin [27]. PI ranged from $2.9 \%-3.1 \%$ at day 1 and reached $4.2 \%-4.9 \%$ at day 7 depending on formulation. From day 7 , rate of proteolysis decreased noticeably, probably due to sub-optimal $\mathrm{pH}$ for enzyme activity due to the intense lactic acidification. Beyond day 21, PI values decreased for all formulation classes. To be sure that this decrease was not due to a problem with the experimental technique used, we measured PI in some samples using the classic Kjeldhal method, which confirmed the decrease in PI values over the last week of process (data not shown). This indicates that some end-products of proteolysis had disappeared, likely consumed by microorganisms present in the products at that point in time, and so could not be detected by the measurement techniques used. The HCA applied to PI values of all formulations segregated four classes of formulations but with lower between-class differences in time-course patterns of PI (Figure 1(a)). The first group that leads to the lowest PI values is formed by the Control, likely reflecting the well-known inhibitor effect of salt against proteolytic enzyme activity. Higher PI values were observed in the $7 \%$-animal fat formulations that contain $0.8 \% \mathrm{KCl}$, regardless of SFO content (K-RSF and K-SFO-RSF). The two other classes are very close in terms of PI values but nevertheless differentiate the formulation $\mathrm{RF}$ that contains $7 \%$ animal fat and $2.8 \% \mathrm{NaCl}$ and the $\mathrm{K}-\mathrm{RS}$ and SFO-RF formulations that contain either $21 \%$ animal fat, $2.0 \% \mathrm{NaCl}$ and $0.8 \% \mathrm{KCl}$ (K-RS) or $7 \%$ animal fat, $3 \% \mathrm{SFO}$ and $2.8 \% \mathrm{NaCl}$ (SFO-RF).

ANOVA and Tukey test highlighted that PI values were strongly affected by partial substitution of $\mathrm{NaCl}$ with $\mathrm{KCl}(p<0.001)$ but unaffected by fat content and the two interactions $(p>0.05)$. These results are in agreement with those of these authors [6] [28] [29] who found higher proteolytic activities in fat-reduced DFS and in dried products made with partial substitution of $\mathrm{NaCl}$ with $\mathrm{KCl}$.

\subsubsection{Rate of Lipolysis}

Figure 1(b) reports the results found for rate of lipolysis. Applying HCA on acidity values measured in end-products for all 6 formulations led to three distinct classes, with two classes counting only one formulation. Indeed, measured acidity value was different in formulations RF and K-RS, whereas all the other formulations belonged to the same class with a mean acidity value of $10.1 \mathrm{mg} \mathrm{KOH}$ per $\mathrm{g}$ of product fat. Moreover, the fact that a lower acid value was found for formulation RF may be explained by its combination of high $\mathrm{NaCl}$ content (2.8\%) and low animal-fat content (7\%). Regarding K-RS, the highest acidity value measured ( $12.3 \mathrm{mg} \mathrm{KOH}$ per $\mathrm{g}$ of product fat) may be attributable to its high animal fat content (21\%) combined with the presence of $0.8 \%$ $\mathrm{KCl}$, unlike the Control formulation that contained only $2.8 \% \mathrm{NaCl}$.

ANOVA and Tukey test showed that rate of lipolysis was highly significantly affected by fat content and salt content $(p<0.001)$ but unaffected by SFO content and all the interactions $(p>0.05)$. These findings are in line with the results reported in [29].

\subsubsection{Time-Course of Lipid Oxidation}

Figure 1(c) charts the time-course of lipid oxidation, showing that HSB values and 
thus oxidation mechanism increased observably over drying time. In addition, HCA pooled the six DFS formulations into just two classes: a first class that leads to the lowest HSB values was formed by the two leanest formulations containing only $7 \%$ animal fat (RF and K-RSF), and a second class covering all other formulations containing more than 7\% fat, including the two that incorporated 3\% SFO. This finding highlights how DFS manufacturers need to be careful incorporating PUFA-rich vegetable oil to avoid excessive lipid oxidation and thus the potential off-flavours.

ANOVA and Tukey test confirmed that lipid oxidation was highly significantly affected by fat level and SFO content $(p<0.001)$ but not by salt content or any of the interactions studied $(p>0.05)$. Liaros et al. [20] found lower lipid oxidation in fat-reduced dried sausages. Other authors have reported similar levels of lipid oxidation when animal fat was partially replaced with vegetable oil such as $20 \%-30 \%$ olive oil [21] or $7.8 \%$ SFO [30]. In contrast, other studies report that using vegetable oils could accelerate lipid oxidation [4]. Finally, here we found no significant effect of salt substitution, contrary to [1] [6] [31], where a significant increase in lipid oxidation in reduced-sodium dry sausages compared to traditional products was observed.

\subsubsection{Time-Course of Protein Oxidation}

Regarding protein oxidation, HCA-based results (Figure 1(d)) led to the formation of two classes as a function of their relative animal fat content regardless of presence or absence of SFO. The first class pools the two $21 \%$-animal fat formulations. The second class pools the four other formulations that correspond to $7 \%$-animal fat formulations containing or not $3 \% \mathrm{SFO}$. In all formulations, thiol-group content decreased with time from the first week to the end of process, from 31.6 - 24.5 to $28.7-21.5 \mathrm{nmol} / \mathrm{mg}$ protein. Since no clear change in protein oxidation appeared with time beyond day 1, protein oxidation visibly occurred rapidly, maybe directly during meat batter preparation, after which there was no subsequent intensification, because the thiol-group-content measured at day 1 was already lower than that measured in the raw meat that ranged from 37 - 38.4 nanomoles DNTP/mg of protein. However, this particular trend may also result from $\mathrm{H}_{2} \mathrm{~S}$ production from cysteine and cystine by microorganisms such as lactic bacteria, yeasts and moulds that experienced exponential growth during the first week of process.

ANOVA and Tukey test confirmed that protein oxidation was very significantly affected by fat content and SFO content $(p<0.001)$. These findings are in line with results published by [30] who reported high lipid oxidation and low protein oxidation in dried sausages made with SFO. Regarding salt content, some authors have reported that salt led to higher oxidation by increasing the pro-oxidant activity of iron and the susceptibility of myofibril to carbonylation [32], whereas other studies have found an antioxidant effect of salt [33].

\subsection{Instrumental and Sensory Characteristics of End-Products}

\subsubsection{Colour Measurements}

Results for instrumental colour measurements (lightness $L^{*}$, redness $a^{*}$ and yellowness 
$b^{*}$ ) are reported in Figure 2. Analysing this figure shows that fat level had very significant effects on lightness $(p<0.001)$. The $21 \%$-animal fat formulations (Control and $\mathrm{K}-\mathrm{RS}$ ) showed higher $\mathrm{L}^{*}$ values than the other 4 formulations (RF, K-RSF, SFO-RF and $\mathrm{K}-\mathrm{SFO}-\mathrm{RSF}$ ), thus confirming previous reports indicating higher $\mathrm{L}^{\star}$ values in higher-fat sausages [17]. The fact that the highest $\mathrm{L}^{*}$ values were found in high-fat sausages could be assigned to a lower percentage of weight losses and low nitrosomyoglobin pigment content in these batches [7] [11] [12]. In addition, the products of formulations K-RS, in which $\mathrm{NaCl}$ was partially replaced by $\mathrm{KCl}$, seemed slightly lighter than control products. Similarly, lighter dry sausages were reported in the literature further to partial substitution of $\mathrm{NaCl}$ with a mixture of $\mathrm{KCl}$ and calcium chloride [16].

Regarding the redness $\left(\mathrm{a}^{\star}\right)$ parameter (Figure $2(\mathrm{~b})$ ), the highest values found were for the 7\%-animal fat formulations not containing 3\% SFO (RF and K-RSF), followed by the 7\%-animal fat formulations that contained 3\% SFO (SFO-RF and K-SFO-RSF), and then the $21 \%$-animal fat formulations (Control and K-RS). This pattern is due to higher myoglobin concentrations in the low-fat products that contained a higher amount of lean meat compared to $21 \%$-animal fat formulations. Statistical analyses showed a very highly significant effect of fat content on $\mathrm{a}^{*}$ values $(p<0.001)$. The literature also

Lightness $L^{*}$

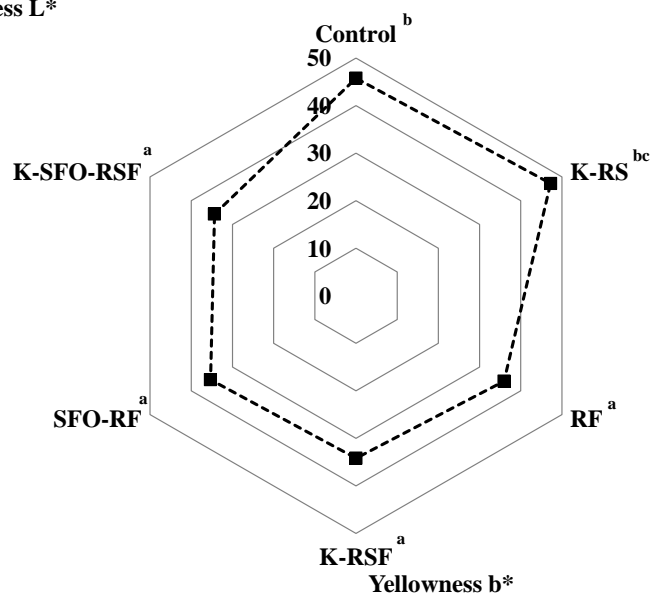

Redness a*

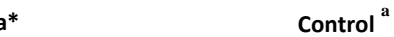

(a) Control 10

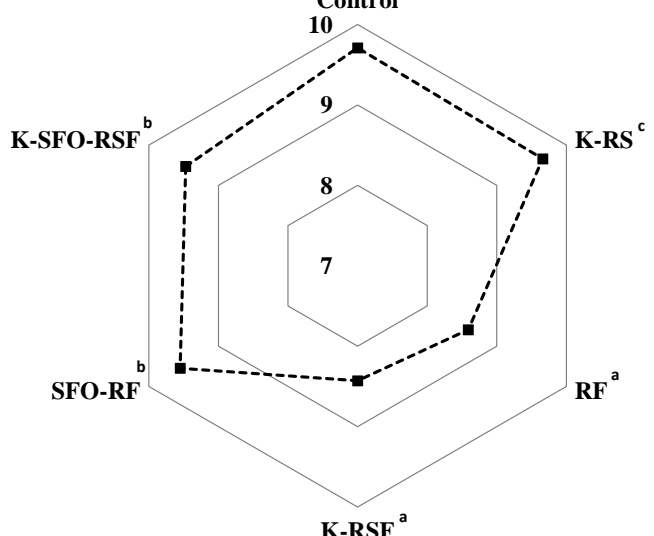

(b)

Figure 2. Instrumental colour measurement: (a) lightness, (b) redness and (c) yellowness of each dry-fermented sausage formulation listed in Table 1. Different letters tagged to formulation name of the graphs denote significant differences between means at $p<0.05$. 
reports higher $\mathrm{a}^{\star}$ values in fat-reduced sausages [3] [7]. In low-fat formulations, using SFO resulted in slightly lower $\mathrm{a}^{\star}$ values (SFO-RF and K-SFO-RSF), and this effect was significant $(p<0.05)$. It has already been reported that dry sausages made with olive oil [12] or SFO have lower $a^{\star}$ values [17].

Moreover, level of animal fat and use of SFO have significant effects on yellowness $(p<$ $0.05)$. The highest $b^{*}$ values found were for the $21 \%$-animal fat formulations, followed by the 7\%-animal fat formulations with 3\% SFO (Figure 2(c)), probably due to their higher unsaturated fatty acid content which would make them prone to colour changes due to oxidation [17].

\subsubsection{Texture Measurements}

The hardness, cohesiveness, elasticity and fragility values measured by TPA-testing are reported in Table 3. Hardness was higher in 7\%-animal fat formulations (RF, K-RSF, SFO-RF and K-SFO-RSF) than 21\%-animal fat formulations (Control and K-RS), reflecting a very significant effect of fat content on final product texture $(p<0.001)$. The literature also reports higher hardness values in low-fat sausages [7] [11] [20] [25] [26]. However, adding vegetable oil (formulations SFO-RF and K-SFO-RSF) also led to clearly harder DFS texture $(p<0.001)$, likely due to the wheat fibre used when preparing SFO or the higher weight losses that occurred when SFO was added. The literature also reports higher hardness values in sausages made with low fat content (6\%) and 3\% wheat fibres [26]. Here, comparing formulations Control vs. K-RS and RF vs. K-RSF, we found that switching from $\mathrm{NaCl}$ to $\mathrm{KCl}$ had very little impact on product hardness, thus confirming results recently published [34], whereas other studies found that partial replacement of $\mathrm{NaCl}$ with $\mathrm{KCl}$ led to harder and less chewy dry sausages [1] [6] [10] [14]. However, Chorizo de Pamplona was found to be softer when salt was replaced with a $\mathrm{NaCl}, \mathrm{KCl}$ and $\mathrm{CaCl}_{2}$ salt mixture [22]. These differences in terms of product hardness could also result from the higher proteolytic activities that generally occurred in salt-reduced formulations.

Cohesiveness was slightly lower in 21\%-animal fat formulations (Control and K-RS)

Table 3. Texture profile analysis (hardness, cohesiveness, elasticity, fragility) performed in the 6 formulations of 29-day-old dry-fermented sausages. Values reported were means \pm standard deviation calculated from 6 independent determinations and values not bearing common superscripts differed significantly at $p<0.05$.

\begin{tabular}{ccccc}
\hline & & Texture profile analysis & \\
\hline Experiments & Hardness & Cohesiveness & Elasticity & Fragility \\
\hline Control & $58.2 \pm 5.4^{\mathrm{bc}}$ & $0.573 \pm 0.032^{\mathrm{ab}}$ & $0.773 \pm 0.003^{\mathrm{a}}$ & $0.932 \pm 0.007^{\mathrm{a}}$ \\
K-RS & $54.6 \pm 3.9^{\mathrm{b}}$ & $0.556 \pm 0.043^{\mathrm{a}}$ & $0.759 \pm 0.003^{\mathrm{a}}$ & $0.932 \pm 0.006^{\mathrm{a}}$ \\
RF & $72.6 \pm 6.1^{\mathrm{de}}$ & $0.588 \pm 0.023^{\mathrm{b}}$ & $0.804 \pm 0.008^{\mathrm{b}}$ & $0.944 \pm 0.002^{\mathrm{bc}}$ \\
K-RSF & $67.7 \pm 6.0^{\mathrm{cd}}$ & $0.611 \pm 0.026^{\mathrm{b}}$ & $0.807 \pm 0.005^{\mathrm{b}}$ & $0.949 \pm 0.007^{\mathrm{c}}$ \\
SFO-RF & $81.5 \pm 6.2^{\mathrm{ef}}$ & $0.615 \pm 0.019^{\mathrm{b}}$ & $0.807 \pm 0.004^{\mathrm{b}}$ & $0.948 \pm 0.007^{\mathrm{c}}$ \\
K-SFO-RSF & $85.0 \pm 8.5^{\mathrm{f}}$ & $0.598 \pm 0.039^{\mathrm{b}}$ & $0.798 \pm 0.002^{\mathrm{b}}$ & $0.946 \pm 0.008^{\mathrm{bc}}$ \\
\hline
\end{tabular}




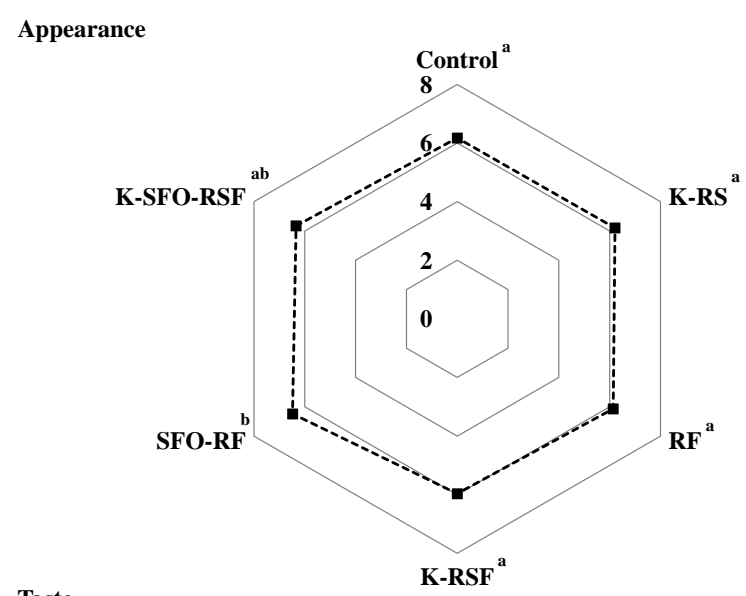

Taste

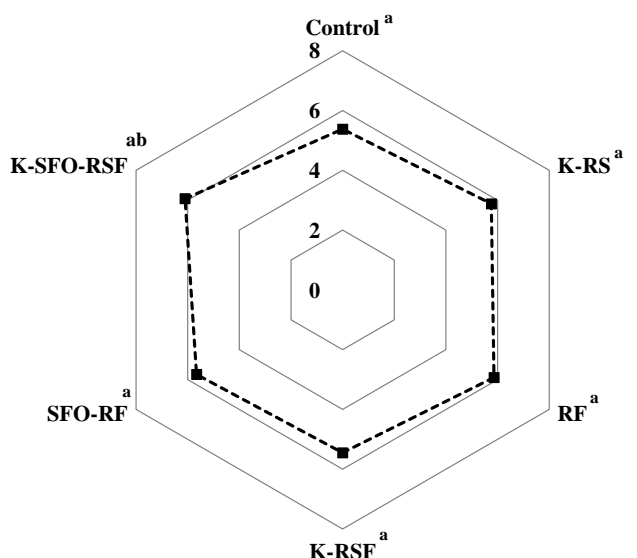

K-RSF than 7\%-animal fat formulations (RF, K-RSF, SFO-RF and K-SFO-RSF). Statistical analysis confirmed the significant effect of fat content $(p<0.01)$ on final product cohesiveness but found no significant effect of SFO and salt content $(p>0.05)$.

Elasticity and fragility were slightly lower in $21 \%$-animal fat formulations (Control and K-RS) than 7\%-animal fat formulations (RF, K-RSF, SFO-RF and K-SFO-RSF), but statistical analysis found a highly significant effect $(p<0.001)$ of fat content on these two textural parameters. We found no statistically significant effect of salt content, type of salt or adding SFO on product elasticity and fragility. However, previous studies report higher fragility, elasticity and cohesiveness values and lower hardness values when non-acid fermented sausages are made with $5 \%$ or $3 \%$ SFO [11] [17].

\subsubsection{Consumer Acceptability Analysis}

Results for consumer acceptability analysis are shown in Figure 3. Except for formulation K-RSF, all other DFS formulations were judged acceptable, as acceptability scores for most of the criteria lay between 5.5 and 6.5/10. The products that scored highest on all the criteria corresponded to formulations K-SFO-RSF and SFO-RF, which scored slightly higher on acceptability than control formulation. Assessors assigned the unacceptability
Mouthfeel

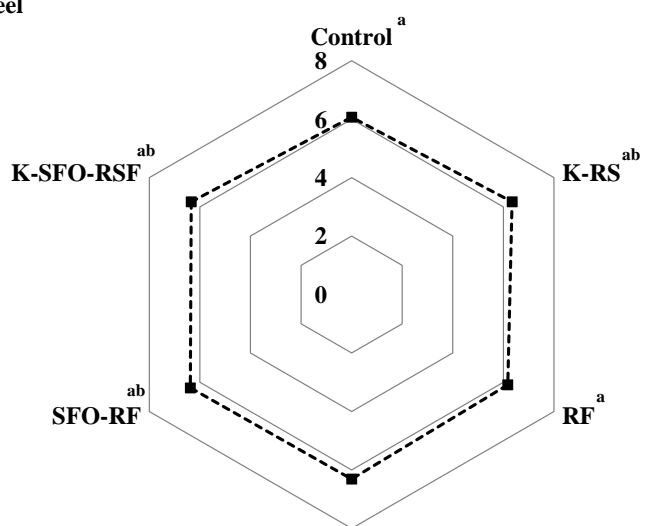

(a)

Aroma

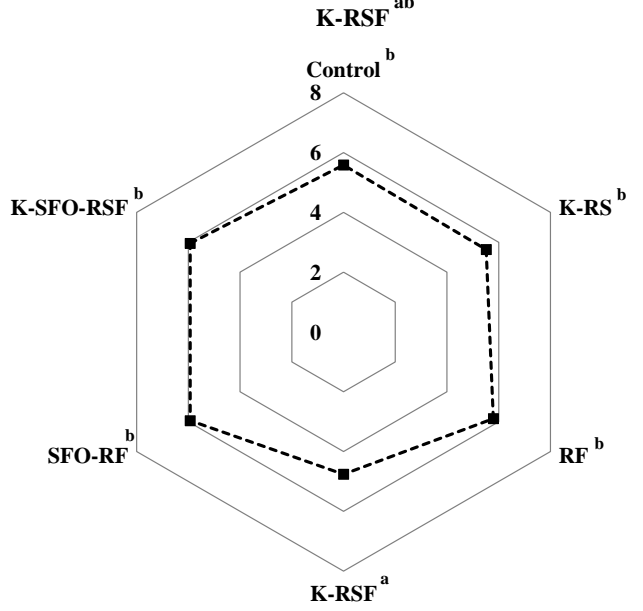

(b)

(d)

Figure 3. Mean consumer acceptability in terms of (a) appearance, (b) mouthfeel, (c) taste and (d) aroma as evaluated by 29 assessors for each dry-fermented sausage formulation listed in Table 1. Different letters tagged to formulation name of the graphs denote significant differences between means at $p<0.05$. 
of formulation K-RSF to aroma and taste defects, citing low aroma, off-flavours and a metallic taste, possibly as a result of the fact that $\mathrm{KCl} / \mathrm{NaCl}$ ratio reached 0.4 . Note that in all low-salt formulations, sausage flavour was always found to be salty enough or even too salty. This can be explained by the likely role of garlic and pepper as saltiness enhancers. The literature also reports good acceptability of odour, flavour, taste and texture in non-acid fermented sausages made with $5 \%$ SFO [11] or with $3 \%$ SFO combined with low sodium content [17].

\section{Conclusion}

This study investigated, at laboratory scale, the effects of combined partial substitutions of $\mathrm{NaCl}$ by $\mathrm{KCl}$ and pork backfat by SFO on physical-chemical and biochemical parameters, instrumental colour and texture attributes and consumer acceptability in six purpose-manufactured DFS formulations. At this scale, some significant differences in terms of physicochemical parameters have been highlighted when the animal fat and sodium contents were modified: a strong impact of fat content and SFO use on final product weight loss, of salt level on final mean $a_{w}$ value, and of animal fat content on final $\mathrm{pH}$ value. Regarding the biochemical parameters, we have shown that 1) proteolysis was strongly affected by partial substitution of $\mathrm{NaCl}$ by $\mathrm{KCl}, 2$ ) end-product lipolysis was strongly impacted both by fat and sodium content, and also 3) protein and lipid oxidations were significantly affected by animal fat level and SFO use. At laboratory scale, further analytical studies are, however, needed to better understand the impact of these new formulations on the volatile and key aroma compounds of these healthier dried sausages. From a practical point of view, the present results globally showed that animal fat and sodium contents can be drastically reduced without leading to unacceptable defects in terms of physical-chemical and biochemical development and with no too marked adverse effect on final textural properties or consumer acceptability: most of the low-fat low-salt products presented practically the same texture and acceptability as full-fat full-salt reference products (control). On the basis of the present results obtained at laboratory scale, combined fat-reduced and sodium-reduced DFS could be manufactured industrially in the near future.

\section{Acknowledgements}

The research leading to these results received funding from the European Union Seventh Framework Programme (FP7/2007-2013) under grant agreement No. 289397 (TeRiFiQ project) and from the "Conseil Régional d'Auvergne" within the framework of the Scientific Communication program “1182" under grant agreement No. 939.92-6574/13968. The authors thank H. Ismail, R. Agouninessouk and the ADIV staff for their technical assistance, and ATT for proofreading the manuscript.

\section{References}

[1] Zanardi, E., Ghidini, S., Conter, M. and Ianieri, A. (2010) Mineral Composition of Italian Salami and Effect of $\mathrm{NaCl}$ Partial Replacement on Compositional, Physico-Chemical and 
Sensory Parameters. Meat Science, 86, 742-747.

http://dx.doi.org/10.1016/j.meatsci.2010.06.015

[2] Ansorena, D. and Astiasarán, I. (2004) The Use of Linseed Oil Improves Nutritional Quality of the Lipid Fraction of Dry-Fermented Sausages. Food Chemistry, 87, 69-74. http://dx.doi.org/10.1016/j.foodchem.2003.10.019

[3] Muguerza, E., Ansorena, D. and Astiasarán, I. (2003) Improvement of Nutritional Properties of Chorizo de Pamplona by Replacement of Pork Backfat with Soy Oil. Meat Science, 65, 1361-1367. http://dx.doi.org/10.1016/S0309-1740(03)00058-5

[4] Severini, C., De Pilli, T. and Baiano, A. (2003) Partial Substitution of Pork Backfat with Extra-Virgin Olive Oil in 'Salami' Products: Effects on Chemical, Physical and Sensorial Quality. Meat Science, 64, 323-331. http://dx.doi.org/10.1016/S0309-1740(02)00204-8

[5] Ruusunen, M. and Puolanne, E. (2005) Reducing Sodium Intake from Meat Products. Meat Science, 70, 531-541. http://dx.doi.org/10.1016/j.meatsci.2004.07.016

[6] Corral, S., Salvador, A. and Flores, M. (2013) Salt Reduction in Slow Fermented Sausages Affects the Generation of Aroma Active Compounds. Meat Science, 93, 776-785. http://dx.doi.org/10.1016/j.meatsci.2012.11.040

[7] Muguerza, E., Fista, G., Ansorena, D., Astiasaran, I. and Bloukas, J.G. (2002) Effect of Fat Level and Partial Replacement of Pork Backfat with Olive Oil on Processing and Quality Characteristics of Fermented Sausages. Meat Science, 61, 397-404. http://dx.doi.org/10.1016/S0309-1740(01)00210-8

[8] Gimeno, O., Astiasarán, I. and Bello, J. (2001a) Calcium Ascorbate as a Potential Partial Substitute for $\mathrm{NaCl}$ in Dry Fermented Sausages: Effect on Colour, Texture and Hygienic Quality at Different Concentrations. Meat Science, 57, 23-29. http://dx.doi.org/10.1016/S0309-1740(00)00070-X

[9] Gimeno, O., Astiasarán, I. and Bello, J. (2001b) Influence of Partial Replacement of $\mathrm{NaCl}$ with $\mathrm{KCl}$ and $\mathrm{CaCl}_{2}$ on Microbiological Evolution of Dry Fermented Sausages. Food Microbiology, 18, 329-334. http://dx.doi.org/10.1006/fmic.2001.0405

[10] Guardia, M.D., Guerrero, L., Gelabert, J., Gou, P. and Arnau, J. (2008) Sensory Characterisation and Consumer Acceptability of Small Calibre Fermented Sausages with 50\% Substitution of $\mathrm{NaCl}$ by Mixtures of $\mathrm{KCl}$ and Potassium Lactate. Meat Science, 80, 1225-1230. http://dx.doi.org/10.1016/j.meatsci.2008.05.031

[11] Mora-Gallego, H., Serra, X., Guardia, M.D., Miklos, R., Lametsch, R. and Arnau, J. (2013) Effect of the Type of Fat on the Physicochemical, Instrumental and Sensory Characteristics of Reduced Fat Non-Acid Fermented Sausages. Meat Science, 93, 668-674. http://dx.doi.org/10.1016/j.meatsci.2012.11.042

[12] Bloukas, J.G., Paneras, E.D. and Fournitzis, G.C. (1997) Effect of Replacing Pork Backfat with Olive Oil on Processing and Quality Characteristics of Fermented Sausages. Meat Science, 45, 133-144. http://dx.doi.org/10.1016/S0309-1740(96)00113-1

[13] Valencia, I., Ansorena, D. and Astiasaran, I. (2006) Nutritional and sensory Properties of Dry Fermented Sausages Enriched with n-3 PUFAs. Meat Science, 72, 727-733. http://dx.doi.org/10.1016/j.meatsci.2005.09.022

[14] Gelabert, J., Gou, P., Guerrero, L. and Arnau, J. (2003) Effect of Sodium Chloride Replacement on Some Characteristics of Fermented Sausages. Meat Science, 65, 833-839. http://dx.doi.org/10.1016/S0309-1740(02)00288-7

[15] Gimeno, O., Ansorena, D., Astiasarán, I. and Bello, J. (2000) Characterization of chorizo de Pamplona: Instrumental Measurements of Colour and Texture. Food Chemistry, 69, 195200. http://dx.doi.org/10.1016/S0308-8146(99)00239-3 
[16] Beriain, M.J., Gomez, I., Petri, E., Insausti, K. and Sarries, M.V. (2011) The Effects of Olive Oil Emulsified Alginate on the Physico-Chemical, Sensory, Microbial, and Fatty Acid Profiles of Low-Salt, Inulin-Enriched Sausages. Meat Science, 88, 189-197.

http://dx.doi.org/10.1016/j.meatsci.2010.12.024

[17] Mora-Gallego, H., Serra, X., Guàrdia, M.D. and Arnau, J. (2014) Effect of Reducing and Replacing Pork Fat on the Physicochemical, Instrumental and Sensory Characteristics throughout Storage Time of Small Caliber Non-Acid Fermented Sausages with Reduced Sodium Content. Meat Science, 97, 62-68. http://dx.doi.org/10.1016/j.meatsci.2014.01.003

[18] Safa, H., Gatellier, P., Lebert, A., Picgirard, L. and Mirade, P.S. (2015) Effect of Combined Salt and Animal Fat Reductions on Physicochemical and Biochemical Changes during the Manufacture of Dry-Fermented Sausages. Food Bioprocess and Technology, 8, 2109-2122. http://dx.doi.org/10.1007/s11947-015-1563-3

[19] Harkouss, R., Mirade, P.S. and Gatellier, P. (2012) Development of a Rapid, Specific and Efficient Procedure for the Determination of Proteolytic Activity in Dry-Cured Ham: Definition of a New Proteolysis Index. Meat Science, 92, 84-88.

http://dx.doi.org/10.1016/j.meatsci.2012.04.017

[20] Liaros, N.G., Katsanidis, E. and Bloukas, J.G. (2009) Effect of the Ripening Time under Vacuum and Packaging Film Permeability on Processing and Quality Characteristics of Low-Fat Fermented Sausages. Meat Science, 83, 589-598.

http://dx.doi.org/10.1016/j.meatsci.2009.07.006

[21] Muguerza, E., Gimeno, O., Ansorena, D., Bloukas, J.G. and Astiasarán, I. (2001) Effect of Replacing Pork Backfat with Pre-Emulsified Olive Oil on Lipid Fraction and Sensory Quality of Chorizo de Pamplona-A Traditional Spanish Fermented Sausage. Meat Science, 59, 251-258. http://dx.doi.org/10.1016/S0309-1740(01)00075-4

[22] Gimeno, O., Astiasarán, I. and Bello, J. (1998) A Mixture of Potassium, Magnesium, and Calcium Chlorides as a Partial Replacement of Sodium Chloride in Dry Fermented Sausages. Journal of Agricultural and Food Chemistry, 46, 4372-4375. http://dx.doi.org/10.1021/jf980198v

[23] Ibañez, C., Quintanilla, L., Irigoyen, A., Garcia-Jalón, I., Cid, C., Astiasarán, I. and Bello, J. (1995) Partial Replacement of Sodium Chloride with Potassium Chloride in Dry Fermented Sausages: Influence on Carbohydrate Fermentation and the Nitrosation Process. Meat Science, 40, 45-53. http://dx.doi.org/10.1016/0309-1740(94)00026-4

[24] Flores, M., Durá, M.A., Marco, A. and Toldrá, F. (2004) Effect of Debaryomyces spp. on Aroma Formation and Sensory Quality of Dry-Fermented Sausages. Meat Science, 68, 439446. http://dx.doi.org/10.1016/j.meatsci.2003.04.001

[25] Olivares, A., Navarro, J.L., Salvador, A. and Flores, M. (2010) Sensory Acceptability of Slow Fermented Sausages Based on Fat Content and Ripening Time. Meat Science, 86, 251-257. http://dx.doi.org/10.1016/j.meatsci.2010.04.005

[26] García, M.L., Dominguez, R., Galvez, M.D., Casas, C. and Selgas, M.D. (2002) Utilization of Cereal and Fruit Fibres in Low Fat Dry Fermented Sausages. Meat Science, 60, 227-236. http://dx.doi.org/10.1016/S0309-1740(01)00125-5

[27] Durá, M.A., Flores, M. and Toldrá, F. (2004) Effect of Debaryomyces spp. on the Proteolysis of Dry-Fermented Sausages. Meat Science, 68, 319-328. http://dx.doi.org/10.1016/j.meatsci.2004.03.015

[28] Ibañez, C., Quintanilla, L., Cid, C., Astiasarán, I. and Bello, J. (1997) Dry Fermented Sausages Elaborated with Lactobacillus plantarum-Staphylococcus carnosus. Part II: Effect of Partial Replacement of $\mathrm{NaCl}$ with $\mathrm{KCl}$ on the Proteolytic and Insolubilization Processes. Meat Science, 46, 277-284. http://dx.doi.org/10.1016/S0309-1740(97)00022-3 
[29] Olivares, A., Navarro, J.L. and Flores, M. (2011) Effect of Fat Content on Aroma Generation during Processing of Dry Fermented Sausages. Meat Science, 87, 264-273.

http://dx.doi.org/10.1016/j.meatsci.2010.10.021

[30] Fuentes, V., Estévez, M., Ventanas, J. and Ventanas, S. (2014) Impact of Lipid Content and Composition on Lipid Oxidation and Protein Carbonylation in Experimental Fermented Sausages. Food Chemistry, 147, 70-77. http://dx.doi.org/10.1016/j.foodchem.2013.09.100

[31] Flores, M., Nieto, P., Ferrer, J.M. and Flores, J. (2005) Effect of Calcium Chloride on the Volatile Pattern and Sensory Acceptance of Dry-Fermented Sausages. European Food Research and Technology, 221, 624-630. http://dx.doi.org/10.1007/s00217-005-0062-6

[32] Perez-Cacho, M.P.R., Galan-Soldevilla, H., Leon-Crespo, F. and Molina Recio, G. (2005) Determination of the Sensory Attributes of a Spanish Dry-Cured Sausage. Meat Science, 71, 620-633. http://dx.doi.org/10.1016/j.meatsci.2005.05.005

[33] Rhee, K.S., Smith, H.G.C. and Terrell, R.N. (1983) Effect of Reduction and Replacement of Sodium Chloride on Rancidity Development in Raw and Cooked Ground Pork. Journal of Food Protection, 46, 578-581.

[34] Dos Santos, B.A., Campagnol, P.C.B., Cavalcanti, R.N., Pacheco, M.T.B., Netto, F.M., Motta, E.M.P., Celeguini, R.M.S., Wagner, R. and Pollonio, M.A.R. (2015) Impact of Sodium Chloride Replacement by Salt Sustitutes on the Proteolysis and Rheological Properties of Dry Fermented Sausages. Journal of Food Engineering, 151, 16-24.

http://dx.doi.org/10.1016/j.jfoodeng.2014.11.015

\section{Submit or recommend next manuscript to SCIRP and we will provide best service} for you:

Accepting pre-submission inquiries through Email, Facebook, LinkedIn, Twitter, etc.

A wide selection of journals (inclusive of 9 subjects, more than 200 journals)

Providing 24-hour high-quality service

User-friendly online submission system

Fair and swift peer-review system

Efficient typesetting and proofreading procedure

Display of the result of downloads and visits, as well as the number of cited articles

Maximum dissemination of your research work

Submit your manuscript at: http://papersubmission.scirp.org/

Orcontact fns@scirp.org 